\title{
Multi-State Taxation of Interstate Sales
}

$\mathbf{T}^{\text {HE }}$ problem of multi-state taxation has recently been given judiof cases, both relating to interstate sales, ${ }^{2}$ the United States Supreme Court has suggested that the commerce clause protects interstate sales transactions froin multiple state tax burdens. The first group comprises two recent cases construing state "use" taxes ${ }^{3}$ in which the Court leaves open the question whether unconstitutional multistate taxation may arise under this type of tax. The second group embraces three cases involving gross receipts from interstate transactions in which the Court indicates the circumstances under which such receipts may be exposed to the risk of multiple tax burdens which the commerce clause forbids.

Prior to 1932 it was regarded as established that all of the activities which in the opinion of the United States Supreme Court were integral parts of interstate sales were conpletely immune from state taxation by virtue of the commerce clause. ${ }^{4}$ These activities included

1 In addition to the interstate commerce cases under discussion here, the problem of multi-state taxation has received recent attention in connection with state inheritance taxes [see Worcester County Trust Co. v. Riley (1937) 302 U. S. 292; Texas v. Florida (March 13, 1939) 59 Sup. Ct. 563, 83 L. ed. Adv. Ops. 549; Curry v. McCanless (May 29, 1939) 59 Sup. Ct. 900, 83 L. ed. Adv. Ops. 865], and with the situs of corporate stock for state tax purposes. Newark Fire Ins. Co. v. State Board of Tax Appeals (May 29, 1939) 59 Sup. Ct. 918, 83 L. ed. Adv. Ops. 889.

2 A sale requiring, contemplating or necessarily involving the transportation of goods across a state line or lines is commonly referred to as an interstate sale. Such a definition attempts to incorporate the judicial requisites to state tax immunity. The writer discusses these requisites in State Sales Taxes and the Conmerce Clause (1936) 24 CarIf. I. REv. 155. In Lockhart, The Sales Tax in Interstate Commerce (1939) 52 HaRv. L. REv. 617, 618, n. 9, an interstate sale is defined for the author's purposes as "a sale negotiated prior to interstate transportation of the goods into the purchaser's state for delivery."

${ }^{8}$ The term "use tax" will be employed as descriptive of the excise taxes, sometimes referred to as compensating taxes, imposed by an increasing number of states complementary to their general sales taxes. An analysis of the problems which gave rise to this type of tax and the problems raised by them is found in Traynor, The California Use Tax (1936) 24 CarIF. L. Rev. 175.

4 See note 2, supra. See also Brown, State Taxation of Interstate Commerce (1933) 81 U. of PA. L. REv. 247; Lowndes, State Taxation of Interstate Sales (1935) 7 Mrss. L. J. 223; Perkins, The Sales Tax and Transactions in Interstate Commerce (1934) 12 N. C. L. Rev. 99; Rodell, A Primer on Interstate Taxation (1935) 44 Yale L. J. 1166; Shoup and Haimoff, The Sales Tax (1934) 34 Cor. L. REv. 809; Waits, Sales Taxes (1932) 10 Tax Mag. 361. 
the solicitation and negotiation of sales, ${ }^{5}$ the transportation of the subject matter of the sale, the delivery to the purchaser ${ }^{6}$ and in some cases installation at the destination. ${ }^{7} \mathrm{~A}$ corollary to this rule was that gross receipts derived from these activities were also immune from state taxation. ${ }^{8}$ The result was that states desirous of taxing such activities performed in connection with purely intrastate sales or gross receipts therefrom, could do so only if they were willing to discriminate against local business. As early as 1887 this state of affairs was called to the attention of the United States Supreme Court. The Court suggested that this condition, if thought injurious to states, would have to be removed by Congress. ${ }^{\circ}$ But that was in 1887.

In 1932 the Court placed its stamp of approval upon a state tax designed expressly to remove the discrimination against local sales of gasoline resulting from the immunity from state taxation enjoyed by interstate sales. In Gregg Dyeing Co. v. Query, ${ }^{10}$ the Court upheld a South Carolina statute imposing a tax on the storage within the state of imported gasoline. The statute expressly excluded from its provisions all gasoline upon which a sales or use tax had been paid to the state, so it was clearly designed to reach only gasoline the sale of which was immune from taxation under the commerce clause. The formal ground of the decision did not disturb the proposition that all the activities which are integral parts of interstate sales are immune from state taxation. It was held simply that storage for use within

5 Robbins v. Shelby County Taxing Dist. (1887) 120 U. S. 489; Heyman v. Hays (1915) 236 U. S. 178 ; Crew Levick Co. v. Pennsylvania (1917) 245 U. S. 292; Real Silk Hosiery Mills v. Portland (1925) 268 U. S. 325.

6 Caldwell v. North Carolina (1903) 187 U. S. 622 ; Norfolk \& Western Ry. v. Sims (1903) 191 U. S. 441 ; Rearick v. Pennsylvania (1906) 203 U. S. 507; Dozier v. Alabama (1910) 218 U. S. 124 ; Crenshaw v. Arkansas (1913) 227 U. S. 389; Rogers v. Arkansas (1913) 227 U. S. 401; Stewart v. Micbigan (1914) 232 U. S. 665; Davis v. Virginia (1915) 236 U. S. 697.

${ }^{7}$ See the discussion of this problem in Browning v. Waycross (1914) 233 U. S. 16, at 23 ; see also York Mfg. Co. v. Colley (1918) 247 U. S. 21, an installation case in which, however, no tax was involved.

8 See Lockhart, op. cit. supra note 2, for an excellent analysis of the development of this whole concept.

9 Robbins v. Shelby County Taxing Dist., supra note 5. At page 498 of the opinion, the Court states: "If the selling of goods by sample and the employment of drummers for that purpose, injuriously affect the local interest of the states, Congress, if apphied to, will undoubtedly inake such reasonable regulations as the case nay demand. And Congress alone can do it; for it is obvious that such regulations should be based on a uniform system applicable to the whole country, and not left to the varied, discordant, or retaliatory enactments of forty different states."

10 (1932) 286 U. S. 472. 
the state after interstate commerce has ended is not an integral part of the interstate sale. More important, however, was the Court's conclusion that, although the tax in question was imposed upon the storage of imported gasoline only, interstate commerce was not unreasonably burdened, since a tax identical in amount applied to gasoline purchased within the state.

In 1876 it was established that even though an activity with respect to interstate commerce is not an integral part thereof, and is, therefore, subject to state taxation, the commerce clause still protects that activity from discriminatory state taxation. In the leading case of Welton v. Missouri, ${ }^{11}$ Missouri imposed a license tax on peddlers of goods from other states. No license tax was imposed on peddlers of domestic goods. The Court held that as to goods within the state that are of foreign origin "the commercial power [of Congress] continues until the commodity has ceased to be the subject of discriminating legislation by reason of its foreign character." 12 Here, of course, discrimination was apparent. In the earlier case of Hinson v. Lott, ${ }^{13}$ it was contended that an Alabama statute imposing a tax of fifty cents a gallon on all imported whiskey offered for sale within the state was an imvalid regulation of interstate and foreign commerce. The state court invalidated that tax as to whiskey imported from foreign countries but upheld it as to whiskey from sister states. ${ }^{14}$ The United States Supreme Court sustained the tax with respect to the whiskey from sister states. It was pointed out that while the tax on whiskey offered for sale applied only to whiskey from other states, another section of the same statute imposed a tax identical in amount on all whiskey manufactured in the state. The opinion states:

"And it is clear that whereas collecting the tax of the distiller was supposed to be the most expedient mode of securing its payment, as to hquors manufactured within the State, the tax on those who sold hquors brought in from other States was only the complementary provision necessary to make the tax equal on all liquors sold in the State. As the effect of the act is such as we have described, and it institutes no legislation which discriminates against the products of sister States, but merely subjects them to the same

11 (1875) 91 U. S. 275. For other cases where taxes have been held to discriminate against interstate commerce, see Ward v. Maryland (1871) 79 U. S. (12 Wall.) 418; Cook v. Pennsylvania (1878) 97 U. S. 566; Tiernan v. Rimker (1880) 102 U. S. 123; Webber v. Virgimia (1880) 103 U. S. 344; Bethlehem Motors Corp. v. Flynt (1921) 256 U. S. 421.

12 Supra note 11, at 282.

13 (1868) 75 U. S. (8 Wall.) 148.

14 Ibid. at 151 . 
rate of taxation which similar articles pay that are inanufactured within the State, we do not see in it an attempt to regulate commerce, but an appropriate and legitimate exercise of the taxing power of the State."15

The distinctions between Binson v. Lott and Gregg Dyeing Co. v. Query are not substantial. In the Hinson case the same statute imposed both taxes. In the Gregg case there were different statutes. ${ }^{10}$ In the Hinson case the tax on domestic goods was in the form of a manufacturer's tax. In the Gregg case the tax on local activities was in the form of a use tax. In the Hinson case it does not expressly appear that the tax was designed to circumvent the rule against state taxation of interstate sales. ${ }^{17}$ In the Gregg case, however, the admitted purpose of the storage tax was to equalize the tax burden between intrastate and interstate sales. ${ }^{18}$

The vital point concerning the Gregg case is this. As shown above, the immunity from state taxation of interstate sales (including all acts thought to be an integral part of such sales) had had the effect that the states could not tax purely intrastate sales or integral parts thereof, without thereby discriminating against local commerce and in favor of interstate commerce. The Gregg case condones and approves a state tax which was confessedly enacted for the very purpose of avoiding this consequence of the immunity from state taxation of interstate commerce. ${ }^{19} \mathrm{It}$ is submitted that while the Court

15 Ibid. at 153.

${ }^{16}$ On this point the Court remarks that "There is no demand in ... [the] Constitution that the State shall put its requirements in any one statute. It may distribute them as it sees fit, if the result, taken in its totality, is within the State's constitutional power." Supra note 10, at 480 .

17 The tax on all whiskey manufactured in the state was said to be the "most expedient mode of securing its payment...." Supra note 13, at 153.

18 The opinion quotes the state court as saying: "Realizing that large users of gasoline either were evading or would evade the payment of the tax imposed under these Acts [acts imposing tax on gasoline dealers], by bringing in gasoline in quantities from without the State, and storing it for their own purposes, the Legislature in 1930 enacted the statute under consideration...." Supra note 10 , at 477 .

10 That the Court does not regard economic considerations as necessarily important is indicated in Southern Pacific Co. v. Gallagher (Jan. 30, 1939) 59 Sup. Ct. 389, 394, 83 L. ed. Adv. Ops. 352, 357, where the Court answered the contention that economically the tax uplueld was the same as a tax admittedly invalid, saying, "It is true, the increased cost to the interstate operator from a tax on installation is the same as from a tax on consumption or operation. This is not significant, The prohibited burden upon commerce between the states is crcated by state interference with that commerce, a matter distinct from the expense of doing business. A discrimination against it, or a tax on its operations as such, is an interference." This distinction is difficult to follow. A tax burden is an economic concept. Granted the problem is to find state interference if the state action under scrutiny is an exercise of taxing power, the interference would seem to be economic. 
continued its formal recognition of the "immunity rule" it robbed it of its substance.

Narrowing the field in which the immunity rule will be applied has, of course, enlarged the field in which the problem of equality of tax burden between intrastate and interstate transactions will be important. The Gregg case recognized "storage for use" as a local activity sufficiently separate from interstate commerce to be subject to the state's taxing power, yet sufficiently related to interstate cominerce to make a discriminatory tax thereon an objectionable burden on interstate commerce. The Gregg case may be said to hold that taxation of an activity related to an interstate transaction while the comparable activity related to intrastate transactions is not taxed, does not establish discrimination if another activity related to intrastate transactions is taxed, so that the tax burden imposed by the state on the two types of transactions is the same. The case held that the tax burden imposed by the state must be equal as to the two types of transactions. It did not hold that the total tax burden on each of the two types must be equal. If the comparison were between total tax burdens, it is apparent that the total tax burden on the interstate transaction would include taxes imposed by the two or more states having jurisdiction over activities related to the interstate transaction. In such a comparison discrimination agamst interstate commerce would be shown if, for example, with respect to an interstate sale, the state of origin imposed a sales tax and the state of destination imposed a use tax, while with respect to intrastate sales the state of destination imposed only a sales tax.

Two cases decided since the Gregg case indicate that the Court is aware that, if the comparison is between total tax burdens, the total tax burden on interstate commerce can be determined only by examiming the tax burdens, if any, imposed by the various states which the commerce touches.

Henneford v. Silas Mason Co. ${ }^{20}$ and Southern Pacific Co. v. Gallagher ${ }^{21}$ involved use taxes imposed by the states of Washington and California respectively. The taxes im both cases were complementary to existing sales taxes, and it was apparent that they were designed to circumvent the "immunity rule." Both taxes were sustained against contentions that they violated the commerce clause. The Washington tax in the Silas Mason case allowed a credit for any

20 (1937) 300 U. S. 577.

21 Supra note 19. 
sales or use taxes paid to any other state, so that an interstate sales transaction, including all the related activities that were proper subjects of state sales or use taxes, would, so far as the state of Washington could legislate, be burdened with only one sales or use tax. This apparent anxiety completely to equalize the tax burden between intrastate and interstate sales transactions assumes that, (1) a sales tax imposed by the state of origin on some activity related to an interstate transaction (but not so closely related as to enjoy immunity from state taxation), imposes a tax burden on that transaction, ${ }^{22}$ and (2) a use tax imposed by the state of destination also imposes a tax burden on that transaction. In allowing the credit for sales or use taxes paid in other states, Washington's statute presented to the Court this interesting question: If the credit had not been provided for, would a sales tax by the state of origin and a use tax by the state of Washington, in legal contemplation, place on the interstate transaction the burden of two taxes, whereas a comparable intrastate transaction would be burdened with only one tax? The fact that the Washington statute did authorize the credit relieved the Court of the necessity of answering the question, and what remarks it did address to the question shed no light on what the answer would have been. On the one hand the Court comments favorably on the real equality of tax burden effected by the credit provision. ${ }^{23}$ On the other hand,

22 It must be remembered that if the sale at the state of origin is an interstate sale the state of origin cannot tax it, at least without apportionment.

23 The Court states, "Equality is the theme that runs through all the sections of the statute. There shall be a tax upon the use, but subject to an offset if another use or sales $\operatorname{tax}$ has been paid for the same thing. This is true where the offsetting tax became payable to Washington by reason of purchase or use within the state. It is true in exactly the same measure where the offsetting tax has been paid to another state by reason of use or purchase there. No one who uses property in Washington after buying it at retail is to be exempt from a tax upon the privilege of enjoyment except to the extent that he has paid a use or sales tax somewhere. Every one who has paid a use or sales tax anywhere, or, more accurately, in any state, is to that extent to be exeinpt from the payment of another tax in Washington.

"When the account is made up, the stranger from afar is subject to no greater burdens as a consequence of ownership than the dweller within the gates. The one pays upon one activity or incident, and the other upon another, but the sum is the same when the reckoning is closed. Equality exists when the chattel subjected to the use tax is bought in another state and then carried into Washington. It exists when the imported chattel is shipped from the state of origin under an order received directly from the state of destination. In each situation the burden borne by the owner is balanced by an equal burden where the sale is strictly local." Supra note 20, at 583-584.

Under this analysis the Court would hold that but for the credit provision the equality it praises would not exist "when the chattel suhjected to the use tax is bought in another state and then carried mto Washington." This, of course, does not mean that it would hold that the Constitution required this type of equality. See note 24 , infra. 
it suggests that it may not be necessary to take account of taxes imposed by other states. ${ }^{24}$

If additional evidence were needed to demonstrate the Court's unsympathetic attitude toward the "immunity rule," that evidence is supplied in the Gallagher case. The problem in this case was complicated by the fact that the property purchased in interstate commerce was immediately put to an interstate use in the taxing state. ${ }^{25}$ Nevertheless, the Court isolated as local activities the activities of "retention and exercise of a right of ownership" the time the interstate transit ended and the interstate use began. Unlike the Washington statute, the California statute made no provision for credit for taxes paid to other states. The Court again postponed the answer to the question first presented in the Silas Mason case by pointing out that:

"Under the Washington statute, there considered, discrimination against interstate commerce, arising from a second exaction for use after a foreign tax on sale, could not exist as provision was made for a credit against the local tax of any such foreign levy. No such problem arises here by evidence, finding or assignment of error even though the California Act does not have this provision. It will be time enough to resolve that argument 'when a taxpayer paying in the state of origin is compelled to pay again in the state of destination." "22

24 Supra note 20, at 587. The Court states, "Yet a word of caution should be added here to avoid the chance of misconception. We have not meant to imply by anything said in this opinion that allowance of a credit for other taxes paid to Washington made it mandatory that there should be a like allowance for taxes paid to other states. A state, for many purposes, is to be reckoned as a self-contained unit, which may frame its own system of burdens and exemptions without heeding systems elsewhere. If there are himits to that power, there is no need to mark then now."

${ }^{25}$ As the Court stated it, "The tax is not sought from personal property used in transactions entirely disassociated from any agency connected with interstate transportation, as builders' supphes for local work in the Silas Mason case, but from tangible personalty purchased out of the state for immediate or subsequent installation in an interstate railway facility." Suspra note 19, at 391, 83 L. ed. Adv. Ops. at 354.

The Court cited Helson \& Randolph v. Kentucky (1929) 279 U. S. 245, as holding that "interstate consumption" is immune from state taxation. It did not actually decide that property installed in an interstate railway facility was being "consumed" in interstate commerce. See note 26 , infra.

26 Supre note 19, at 393, 83 L. ed. Adv. Ops. at 357. The Court said, "We think there was a taxable moment when the former [special order articles installed immediately on arrival at the California destination] had reached the end of their interstate transportation and had not begun to be consumed in interstate operation. At that moment, the tax on storage and use-retention and exercise of a right of ownership, respectively-was effective." These events were found by the Court to be not so close to or inseparably intertwined with interstate commerce as to be a part of it. It is submitted that the reason why this was so is because the Court said so.

27 Supra note 19, at 391, 83 L. ed. Adv. Ops. at 354. The last clause in this quotation will be recognized as a part of the Silas Mason opinion. 
At least, the Court has thus twice suggested the type of case which will compel an answer-a taxpayer paying in the state of origin being compelled to pay again in the state of destination. ${ }^{28}$

In the early case of Hinson v. Lott ${ }^{29}$ a distiller's tax was construed as complementary to a tax on sellers of imported whiskey. The combined effect of the two taxes was to impose a tax of fifty cents a gallon on all whiskey sold in the state. Suppose the evidence in the Gallagher case had been that the state of origin imposed a manufacturer's tax measured by gross receipts from sales of the manufactured articles. Suppose further that the evidence showed that this tax was passed on to the purchaser, i.e., the taxpayer now being compelled to pay a use tax at the state of destination. Would this be the type of case for which the Court is waiting? ${ }^{30}$ While both the manufacturer's tax and the sales tax imposed at the state of origin and measured by gross sales have been sustained notwithstanding the goods manufactured and sold were subsequently used in another state, the questions here presented were not cliscussed. ${ }^{31}$ In the Silas Mason case $^{32}$ the Court pointed out that, "A state, for many purposes, is to be reckoned as a self-contained unit, which may frame its own system of burdens and exemptions without heeding systems elsewhere." We are left, however, to ponder on the precise scope of "many purposes."

Having decided that where the state levies a tax upon a local activity, related to an interstate sale (but not so closely related as to

28 It will be observed that while the Court in both cases speaks of a taxpayer paying in one state and then being compelled to pay again in another, literally interpreted such a case might never arise for the reason that under most state sales tax statutes the seller and not the purchaser is the taxpayer. Actually the purchaser has the tax passed on to him and it seems certain that this is the situation the Court has in mind; that is, an interstate transaction when a sales tax actually is paid in one state and a use tax actually is paid in another state.

29 Supra note 13.

30 To be sure, the Washington credit provision was limited to sales and use taxes paid to other states, but if the payment of taxes to other states raises a question, the question certainly could not be confined to certain taxes named in the statute allowing the credit.

31 In American Mfg. Co. v. St. Louis (1910) 250 U. S. 459, the Court upheld a manufacturer's tax measured by gross sales including sales of goods delivered from a warehouse outside the taxing state. No question was presented as to taxes imposed by states where the property was sold. Superior Oil Co. v. Mississippi [(1930) 280 U.S. 390] is certainly authority for the proposition that the state of origin may tax an intrastate sale and measure the tax by gross receipts even though the buyer immediately takes the goods into another state and there uses them.

32 Supra note 20, at 587. 
be regarded as an integral part of interstate commerce), no discrimination against interstate commerce results, if the state imposes a tax equal in amount on some activity related to comparable local sales transactions, at least, in the absence of a showing that an activity related to the interstate sale has been taxed by another state, the Court may in the future hold that for the purpose of taxing local activities related to interstate sales, the state "is to be reckoned as a self-contained unit," and that whether or not discrimination against interstate commerce exists is determined by examination of the system of revenue of that state alone.

On the other hand, the Court may hold that notwithstanding the subject of the tax is a local activity, its relationship to interstate sales requires that consideration be given to the fact that taxes have been paid to other states on activities related to the same interstate sales. Should the Court so hold, it would then be compelled to distinguish between the various types of state taxes on subjects more or less related to interstate sales, in order properly to determine the degree to which they are paid out of interstate commerce. The complications involved in this latter task alone argue against the adoption of such a principle.

The distinction which the Court continues to make between activities that are integral parts of interstate commerce and those that are not finds little support in economic fact. The complete abandonment of the "immunity rule," with proper safeguards against discriminations against interstate commerce, would allow for greater recognition of the economic realities in this field of taxation. The cases now to be discussed indicate a tendency in this direction.

In Western Live Stock v. Bureau of Revenue, ${ }^{33}$ the Court upheld a New Mexico privilege tax measured by gross receipts as applied to the business of publishing magazines. The tax was measured by gross receipts from the sale of advertising space. A precedent for upholding the tax was found in American Manufacturing Co. v. St. Louis, ${ }^{34}$ where the Court sustained a tax on the privilege of manufacturing measured by total gross receipts froin sales, both intrastate and interstate, of the manufactured goods. The use of gross receipts as the measure of the tax was construed by the Court as simply a convenient method of arriving at the value of the admittedly taxable

33 (1938) 303 U.S. 250.

34 Supra note 31. 
privilege of manufacturing. In the Western Live Stock case ${ }^{36}$ the Court carefully construed the tax as laid on the local business "of preparing, printing and publishing magazine advertising...." Gross receipts from the sale of advertising space were said to be "a convenient ineans of arriving at an equitable measure of the burden which may be imposed on an admittedly taxable subject matter." ${ }^{30}$ It being determmed that the tax was on a local business, there were several cases to support the validity of the measure. ${ }^{37}$ It would seem, however, that the tenuous distinctions which the Court had from time to time made in deciding whether a business or activity was local and subject to state taxation or interstate and immune therefrom, led the Court to seek a more substantial and rational approach. ${ }^{38}$

Instead of denying that the method of taxation under observation taxed interstate values, the Court admitted that insofar as the gross receipts from advertising were increased by the required interstate circulation of the magazme, interstate value was taxed by its inclusion in the gross receipts by which the tax was measured. According to Mr. Justice Stone, the tax was valid, notwithstanding, for the reason that it

35 Supra note 33 , at 251 . A footnote to the opinion recites the state statute as imposing a tax " 'measured by the amount or volume of business done, against the persons, on account of their busimess activities, engaging, or contmuing, within the State . . . in any business as herein defined, and in the amounts determined by the apphication of rates against gross receipts, as follows: ... At an amount equal to two per cent of the gross receipts of any person engaging or continuing in any of the following busmesses: ...publication of newspapers and magazines (but the gross receipts of the business of publishing newspapers or magazines shall include only the amounts received for the sale of advertising space.)....'" Ibid. at 251-252. The subject of the tax, according to the statute as quoted, plainly is "publication of newspapers and magazines." The Court, however, construed the subject from the language of the measure. There may have been some doubt as to whether publishing was a valid subject.

$36 \mathrm{Ibid}$. at 258.

37 The steps in establishing the propriety of using gross receipts from sales of advertising space as the measure of the tax on the local business of preparing printing and publishing magazine advertising are: (1) "No one would doubt that the tax on the privilege would be valid if it were measured by the amount of advertising space sold. Utah Power \& Light Co. v. Pfost ... [286 U. S. 165]; Federal Compress \& W. Co. v. McLean, 291 U. S. 17," (2) "or by its value. Otiver Iron Mining Co. v. Lord, 262 U.S. 172; Hope Natural Gas Co. v. Hall, 274 U. S. 284 ;" (3) selhing price or gross receipts is a convenient measure of value. Ibid.

38 After upholding the tax on the authority of the American Mfg. Co. case, the Court said that the tax "finds support in reason, and in the practical needs of a taxing system which, under constitutional limitations, must accommodate itself ...." Ibid. 
"... is not one which in form or substance can be repeated by other states in such manner as to lay an added burden on the interstate distribution of the magazine.... It is not measured by the extent of the circulation of the magazine interstate. All the events upon which the tax is conditioned-the preparation, printing and publication of the advertising matter, and the receipt of the sums paid for it-occur in New Mexico and not elsewhere. All are beyond any control and taxing power which, without the commerce clause, those states could exert through its dominion over the distribution of the magazine or its subscribers. The dangers which may ensue from the imposition of a tax measured by gross receipts derived directly from interstate commerce are absent." 39

Making a bold departure from orthodoxy, Mr. Justice Stone implies that, contrary to the prevailing notion, a state legally can tax interstate values, where they cannot be taxed again by any other state. The opinion leaves some doubt as to why the interstate value added to the gross receipts from advertising could not have been taxed by other states. It seems to be assumed that no taxable activity occurring outside of New Mexico contributed to this added value. ${ }^{40}$

The tax on the business of furnishing advertising space, measured by gross receipts from advertising, was valid for two reasons: (1) Construed as a tax on local business of preparing, printing and publishing magazine advertising, gross receipts from the sale of advertising space, though augmented by required interstate circulation, was, under the authority of American Manufacturing Co.v. St. Louis, a proper measure of the value of the local privilege.11 (2) Construed

39 Ibid. at 260.

40 The opinion states that "All the events upon which the tax is conditioned... occur in New Mexico and not elsewhere. All are beyond any control and taxing power which, without the commerce clause, those states could exert through its dominion over the distribution of the magazine or its subscribers." Ibid. Earlier in the opinion it is said that "So far as the advertising rates reflect a value attributable to the maintenance of a circulation of the magazine interstate, we think the burden on the interstate business is too remote and too attenuated to call for a rigidly logical application of the doctrine that gross receipts froin interstate commerce may not be made the measure of a tax." Ibid. at 259. It has been suggested that the Court is distinguishing between gross receipts derived directly from interstate cominerce and those derived indirectly. See Note (1939) 52 HARv. L. REv. 502.

41 The Court pointed out that while the tax in the American Mfg. Co. case was measured by gross receipts from the sale of the commodity, the New Mexico tax excluded from the measure all gross receipts from the sale of the magazine. On the other hand, it did not appear that the purchase price of the property involved in the American Mfg. Co. case was greater in the case of out-of-state sales than in the case of local sales. In the Western Live Stock case advertisers paid more for the interstate circulation of advertisements than they paid for their local circulation; at least this is implicit in the Court's talk about the gross receipts being "enhanced hy appellant's circulation of their journal interstate..." Stupra note 33, at 259. 
as a tax on the gross receipts from advertising, including the addition thereto resulting from required interstate circulation, no other state can tax that interstate value.

In laying the foundation for the second ground Mr. Justice Stone implied that in cases where the interstate values taxed are gross receipts from interstate commerce, if the receipts are derived from activities performed in more than one state, the tax will be upheld if limited to the gross receipts fairly apportioned to the local activities. Re-interpreting former decisions involving state taxes measured by gross receipts from interstate commerce, Mr. Justice Stone contends that:

"The vice characteristic of those which have been held invalid is that they have placed on the commerce burdens of such a nature as to be capable, in point of substance, of being imposed ... or added to ... with equal right by every state which the commerce touches, merely because interstate commerce is being done, so that without the protection of the commerce clause it would bear cumulative burdens not imposed on local commerce.... The multiplication of state taxes measured by the gross receipts from interstate transactions would spell the destruction of interstate commerce and renew the barriers to interstate trade which it was the object of the commerce clause to remove." 42

Thus the commerce clause is interpreted, not as prohibiting state taxation of interstate transactions, but rather as prohibiting the imposition of cumulative state tax burdens not imposed on local commerce. The significance of this "cumulative burdens" doctrine is emphasized by a comparison of the language of Mr. Justice Stone just quoted, with the language of Mr. Justice Bradley setting forth the immunity rule in Leloup v. Port of Mobile ${ }^{43}$ to the effect that:

"In our opinion such a construction of the Constitution leads to the conclusion that no State has the right to lay a tax on interstate commerce in any form, whether by way of duties laid on the transportation of the subjects of that commerce, or on the receipts derived from that transportation, or on the occupation or business of carrying it on, and the reason is that such taxation is a burden on that commerce, and amounts to a regulation of it, which belongs solely to Congress."

Whether the major implications of the cumulative burdens doctrine will be followed, only the future can tell. The doctrine has been

42 Ibid. at 255-256.

43 (1888) 127 U. S. 641, 648. 
referred to and even relied on ${ }^{44}$ in several cases decided since the Western Live Stock case. State taxes measured by gross receipts from interstate transactions were invalidated in J.D. Adams Manufacturing Co. v. Storen, ${ }^{45}$ and Gwin, White \& Prince, Inc. v. Henneford. ${ }^{46}$ In both, however, the cumulative burdens doctrine is referred to with approval. The Storen case involved Indiana's Gross Income Tax Act, ${ }^{47}$ which imposed a tax on the gross income of every resident of the state and the gross income of every non-resident derived from sources within the state. The complaining taxpayer was a domestic corporation manufacturing and selling road machinery and equipment. Its principal place of business and factory were located in Indiana, but eighty per cent of its sales were made to customers in other states and foreign countries "upon orders taken subject to approval at the home office." 4 Mr. Justice Roberts writing for the majority, immediately after construing the tax as "what it purports to be-a tax upon gross receipts from commerce," points out that:

"The vice of the statute as applied to receipts from interstate sales is that the tax includes in its measure, without apportionment, receipts derived from activities in interstate commerce; and that the exaction is of such a character that if lawful it may in substance be laid to the fullest extent by States in which the goods are sold as well as those in which they are manufactured. Interstate commerce would thus be subjected to the risk of a double tax burden to which intrastate commerce is not exposed, and which the commerce clause forbids." 49

44 In J. D. Adams Mfg. Co. v. Storen (1938) 304 U. S. 307, the Court bases its decision on the cumulative burdens doctrine, but the cases relied on support the inmunity rule. At two different points in the majority opinion, however, Mr. Justice Roberts condemns the tax as reaching gross receipts from interstate coununerce, "indiscriminately" and "without apportionment." See Note (1939) 27 CALIF. L. REv. 336.

45. Supra note 44.

46 (1939) 59 Sup. Ct. 325, 83 L. ed. Adv. Ops. 276.

47 Ind. Acts 1933, p. 388.

48 Supra note 44 , at 309.

$49 \mathrm{Ibid}$. at 311 . A majority of the Indiana Supreme Court had construed the statute as imposing "a tax upon all who are domiciled within the state, based upon the privilege of domicile, and transacting business, and receiving gross incoune, within the state, and measured by the aunount of gross income." Storen v. J. D. Adauns Mfg. Co. (1937) 212 Ind. $343,351,7$ N. E. (2d) 941, 944. In dissenting from this view, Judge Treanor reinarked: "But I am convinced that ... our present Gross Income Act does not impose a tax upon the privilege of engaging in the business of manufacturing. In so far as the tax in question may be considered a privilege tax, it inust be treated as a tax upon the privilege of receiving gross income.... It is my opinion that the tax inposed by our Gross Income Act is a tax upon gross income or gross receipts." Ibid. at 370-371, 7 N.E. (2d) at 952-953. Mr. Justice Roberts was in substantial agreement with Judge Treanor as to the subject of the tax. He pointed out that it was not on the privilege of domicile 
A footnote to this proposition contains the lone citation of the Live Stock case, decided three months before. The tax in the Storen case was objectionable, not simply because it was construed to be laid on gross receipts from interstate commerce, but because it was laid on those gross receipts without apportionment. The clear inference here is that the commerce clause does not prohibit a state tax directly on gross receipts from interstate commerce provided the tax is limited to gross receipts apportioned to activities in interstate commerce with a situs in the taxing state. The Groin case involved a Washington tax on business activities measured by gross receipts including receipts from interstate commerce. It is clear that Mr. Justice Stone was of the opinion that there was no local business separate from interstate commerce subject to taxation as such. ${ }^{50} \mathrm{It}$ is also clear that he was of the opimion that the taxability of the gross receipts did not depend on the existence of such a local business. It seemed clear to hin that his opimion in the Western Live Stock case recognizes the proposition that not every state tax "laid upon gross receipts derived from interstate commerce is forbidden," $" 1$ and he says so in so many words. What is forbidden, he says, is a state statute that "undertakes to lay a privilege tax measured by gross receipts derived from activities in such commerce which extend beyond the territorial limits of the taxing state... at least when not apportioned to the activities carried on within the state...." ${ }^{52}$ The plain implications are, (1) that the privilege of engaging in an interstate activity within the state is not immune from state taxation if measured by receipts fairly apportioned to that activity, ${ }^{53}$ and (2) that independently of the taxability

alone for it extended to non-residents; it was not for privilege of transacting business for it extended to those who conducted no business; it was not for producing or manufacturing; it was not in lieu of ad valorem property taxes.

$50 \mathrm{He}$ concludes that "We need not stop to consider which, if any, of appellant's activities in carrying on its business are in themselves transportation of the fruit in interstate or foreign coununerce. For the entire service for which the counpensation is paid is in aid of the shipment and sale of merchandise in that commerce. Such services are within the protection of the commerce clause..." Supra note 46, at 327, $83 \mathrm{~L}$. ed. Adv. Ops. at 278.

51 Ibid.

52 Ibid. at 327, 83 L. ed. Adv. Ops. at 279 . Italics added.

53 There is some confusing language in the opinion suggesting that the privilege of engaging in interstate commerce is immune from state taxation as such. It is said that an unapportioned gross receipts tax "burdens the commerce in the same manner and to the same extent as if the exaction were for the privilege of engaging in interstate commerce...." This statement may be limited by the clause immediately following it, reading, "and would, if sustained, expose it to multiple tax burdens, each measured by the entire amount of the commerce, to which local commerce is not subject." Ibid. If the tax 
of an activity as a privilege, the gross receipts fairly apportioned to the activity are subject to state taxation. ${ }^{54}$ Either implication presents the problem of fairly apportioning the gross receipts to the interstate activity occurring in the taxing state.

In the Western Live Stock case it was considered proper to apportion to the taxing state the entire amount of whatever interstate value there was in the gross receipts from the sale of advertising space. In the Groin case Mr. Justice Stone revives Ficklen v. Shelby County Taxing District, ${ }^{55}$ directing attention to the fact that in that case "Although the tax, measured by gross receipts, to some extent burdened the commerce ... . it was apportioned exactly to the activities taxed, all of which were intrastate...." ${ }^{" 56}$ An examination of the Ficklen case reveals that the gross receipts by which the tax was measured were in the form of commissions received for negotiating sales for non-resident firms. It thus appears that the activities from which the commissions arose involved soliciting orders for sales and forwarding the same to the non-resident principals. The measure of the tax was limited to commissions and did not include the amounts which went to the non-resident seller. It is true, therefore, that all the acts giving rise to the commissions took place within the territorial confines of Shelby County. This analysis would not have been possible if the tax had been measured by gross sales negotiated, rather than gross commissions received. It suggests that a statute imposing a local gross receipts tax at the place where the sales are confirmed by the principals, must so apportion the gross receipts of the principals that amounts representing commissions will not be exposed to more than one tax.

is bad only because sustaining it will expose interstate commerce to multiple tax burdens, a fair apportionment would cure it; the tax, however, would still be for the privilege of engaging in interstate activities.

54 There is no doubt that the language of the opinion supports this implication. It is said: "It has often been recognized that 'even interstate business must pay its way' by bearing its share of local tax burdens, ... and that in consequence not every local tax laid upon gross receipts derived from participation in interstate commerce is forbidden. See Western Live Stock v. Bureau of Revenue..." Ibid. at 327, 83 L. ed. Adv. Ops. at 278. Of course, the Western Live Stock case was not decided on 'this ground, at least not solely. If it is true that a state may lay a tax on gross receipts from interstate commerce, it is because the Court said so in the Western Live Stock case.

55 (1892) 145 U. S. 1. While the bolding in this case bas never been definitely repudiated the Court has treated it as "near the boundary line of the State's power." Brennan v. Titusville (1894) 153 U. S. 289, 306. See also Stockard v. Morgan (1902) 185 U.S. 27, 34; Crew Levick Co. v. Pennsylvania, supre note 5.

${ }^{6}$ Supra note 46 , at 328, 83 L. ed. Adv. Ops. at 279. 
The inference that the commerce clause does not immunize from state taxation gross receipts from interstate activity unless the tax exposes interstate values to the risk of cumulative tax burdens, particularly in view of Mr. Justice Stone's new interpretation of the Ficklen case, raises serious doubts as to the present standing of Puget Sound Stevedoring Co. v. Tax Commission, ${ }^{57}$ decided about three months prior to the Western Live Stock case. A unanimous court there held that gross receipts from the activity involved in loading and unloading vessels engaged exclusively in interstate or foreign commerce legally may not be included in the measure of a state tax upon the privilege of engaging in the general stevedoring business within the state. Here all the activities from which the gross receipts arose occurred in the taxing state. It would seem, therefore, that $\mathrm{Mr}$. Justice Stone's statement concerning the tax upheld in the Ficklen case that "Although the tax, measured by gross receipts, to some extent burdened commerce ... it was apportioned exactly to the activities taxed, all of which were intrastate," is applicable to the tax in the Puget Sound case. The formal distinction, of course, is that in the Ficklen case the Court found the activities to be intrastate in the sense that they were not a part of interstate commerce, while in the Puget Sound case the Court found the activities to be interstate although occurring entirely within the territorial confines of the taxing state. This distinction has nothing to coinmend it if the purpose to be accomplished under the commerce clause as applied to state taxes is the prevention of exposure to cumulative burdens.

Where it is conceded that the activities froin which gross receipts are derived are performed in more than one state, a formula for allocating a proportion of the gross receipts to the various activities performed in the taxing state will present to the Court the question whether there is a fair apportionment. Unfortunately there are only a few judicial guide-posts in the field of apportionment of interstate gross receipts. In discussing this problem of fair apportionment in the Western Live Stock and Gwin cases, Mr. Justice Stone calls attention to several cases involving state taxes measured by interstate receipts apportioned to the taxing state. A majority of them involved the apportionment of gross receipts from interstate transportation, where the problem is comparatively simple. Interstate transportation activities are essentially similar in the several states wherein they are conducted. Where, as in the recent cases, the gross receipts are from

67 (1937) 302 U.S. 90. 
the interstate sale of commodities, fair apportionment of the gross receipts to the different activities presents a different, and, it is submitted, more difficult problem, because of the fact that the interstate sales involved different kinds of activity in two or more states.

In the Storen and Groin cases the sale of goods gave rise to the gross receipts involved. In the Storen case the state where the goods were manufactured sought to impose a tax upon the manufacturer measured by the gross receipts from the sale of all the goods manufactured. From the statement of the facts in the majority opinion by Mr. Justice Roberts, it appears that some of the interstate sales activities occurred at the factory. It was there that orders were approved, shipments made and payments remitted. Since, however, eighty per cent of the sales were made to customers in other states and foreign countries, some of the activities performed in the consummation of these sales occurred outside the taxing state. Presumably orders were taken there. Accordingly under the cumulative burdens doctrine some of the gross receipts should have been allocated to these activities; but there is not the slightest suggestion as to how this allocation should be made.

In the Grein case the state of Washington imposed a tax for the act or privilege of engaging in business activities within the state, measured by the gross income of the business. The taxpayer had a place of business in the state. Its business was described by the Court as follows:

"... it makes sales and deliveries of the fruit in other states and in foreign countries, collects the sales prices and remits the proceeds to its principals after deducting transportation charges, certain expense allowances and its own compensation. In the course of the business the fruit is shipped from the states of origin ... to other states and foreign countries, sometimes directly to the purchasers, but more often it is consigned to appellant [taxpayer] at extra-state points from which it is diverted by appellant to purchasers who buy the fruit while in transit, or where it is stored pending sale. Representatives of appellant at numerous points without the state negotiate sales of the fruit on behalf of appellant and on its approval execute written contracts of sale, effect delivery of the shipments to purchasers, collect the purchase price and remit it to appellant in Washington, where it is accounted for to the shippers." 5 s

It is apparent from this analysis that many of the activities performed in the consummation of the sales were performed outside

58 Supra note 46, at 326, 83 L. ed. Adv. Ops. at 277. 
the state of Washington. The tax, however, was not measured by gross receipts from sales, but by the gross income of the taxpayer which was a stipulated amount for each box of fruit sold. But as the Court pointed out, "Both the compensation and the tax laid upon it are measured by the amount of the commerce-the number of boxes of fruit transported from Washington to purchasers elsewhere. ..." The Court invalidated the tax as a burden on interstate commerce but inferred that the tax would have been upheld if measured by only that portion of the appellant's gross income fairly allocable to activities which appellant performed in Washington. Approval of orders, preparation of shipments, accounting to its principals, are activities which doubtless the Court had in mind. Outside the state, however, were the activities of the taxpayer's numerous representatives-the negotiation of sales, execution of contracts subject to approval, actual delivery to purchasers, and collection of the sales price for remittance to the home office in Washington. Here again, there is no suggestion as to how the gross income should be apportioned between the several activities from which it is derived.

In the Western Live Stock case, Mr. Justice Stone cites two cases involving the allocation of net income that shed some light on the problem of allocating gross income from sales activities. Underwood Typewriter Co. v. Chamberlain ${ }^{60}$ involved the constitutionality of a Connecticut tax on corporations measured by their net income. In the case of corporations carrying on business within and without the state the tax was ineasured by the proportion of net income earned from business carried on within the state. According to the opinion written by Mr. Justice Brandeis, "If the company's net profits are derived principally from ownership, sale or rental of real property, or from the sale or use of tangible personal property, the tax is imposed on such proportion of the whole net income, as the fair cash value of the real and tangible personal property within the State bears to the fair cash value of all the real and tangible personal property of the company." 61

The taxpayer's return declared that its net profits during the preceding year were principally from tangible personal property and that the proportion of its real and tangible personalty in the state was forty-seven per cent. It objected to paying a tax on forty-seven per cent of its net profits, but the Court sustained the tax, saying:

50 Ibid. at 327, 83 L. ed. Adv. Ops. at 278.

60 (1920) 254 U. S. 113.

Gal Ibid. at 118 . 
"The profits of the corporation were largely earned by a series of transactions beginning with manufacture in Connecticut and ending with sale in other States.... The legislature in attempting to put upon this business its fair share of the burden of taxation was faced with the impossibility of allocating specifically the profits earned by the processes conducted within its borders. It, therefore, adopted a method of apportionment which, for all that appears in this record, reached, and was meant to reach, only the profits earned within the State." ${ }^{62}$

This case suggests that if a state provides some formula for apportioning gross receipts, the burden is on the taxpayer to show that the method of apportionment is "inherently arbitrary or that its application ... produced an unreasonable result." 13

A more complicated apportionment formula was sustained in Bass, Ratcliff \& Gretton, Ltd. v. State Tax Commission, ${ }^{64}$ which also involved a tax measured by net profits of the preceding year. As in the Underwood Typewriter case, the profits were derived principally from sales. Under the New York tax law involved, the tax in the case of corporations doing business within and without the state was on the portion of net income which the aggregate value of specified classes of assets of the corporation within the state bore to the aggregate value of all such classes of assets wherever located. The classes of assets included in addition to real and personal property, bills and accounts receivable and a certain percentage of the shares of stock owned in other corporations. Relying principally upon the Underwood Typewriter case, the Court upheld the tax, remarking:

"Nor do we find that the method of apportioning the net income on the basis of the ratio of the segregated assets located in New York and elsewhere, was inherently arbitrary or a mere effort to reach profits earned elsewhere under the guise of legitimate taxation.... We see nothing arbitrary in also including bills and accounts receivable...."

The problem of apportioning gross receipts under the many modern gross receipts and gross sales taxes will doubtless be solved largely by the method of trial and error. State taxes on or measured by gross receipts in general will be applicable to a wide variety of business activities, thus necessitating a flexible formula. The California Bank

62 Ibid. at 120-121.

63 Ibid. at 121.

04 (1924) 266 U. S. 271.

65 Ibid. at 282-283. 
and Corporation Franchise Tax Act ${ }^{66}$ imposes a tax measured by net income. Section 10 of the Act provides in part:

"... if the entire business of such bank or corporation is not done within this state, the tax shall be according to or measured by that portion thereof which is derived from business done within this state. The portion of net income derived from business done within this state shall be determined by an allocation upon the basis of sales, purchases, expenses of manufacture, pay roll, value and situs of tangible property, or by reference to these or other factors, or by such other method of allocation as is'fairly calculated to assign to the state the portion of net income reasonably attributable to the business done within this state and to avoid subjecting the taxpayer to double taxation."

A somewhat similar formula might well be used by a state seeking to allocate gross receipts from interstate commerce.

The following conclusions may he drawn from the decisions defining the commerce clause limitations on state taxes with respect to activities related to interstate sales.

1. The state of origin may impose a tax on the production or inanufacture of goods sold in interstate commerce and measure the tax by gross receipts from such sales. The tax is imposed on a local activity distinct from interstate commerce. The use of gross receipts (including gross receipts from interstate sales) as the measure is simply a convenient means of arriving at the value of the privilege of producing or manufacturing. The fact that the same gross receipts may be used as the measure of a tax on the privilege of selling imposed by states in which the goods are sold, does not, in legal contemplation, present a question of objectionable multi-state taxation. Certain portions of the Western Live Stock opinion raise some doubts as to the propriety of measuring a tax on a local privilege by unapportioned gross receipts from interstate sales. ${ }^{67}$ These doubts are dispelled by

66 Cal. Stats. 1929, p. 19, as amended ibid. p. 1555; ibid. 1931, pp. 60, 64, 2225; ibid. 1933, pp. 40, 687, 692, 869; ibid. 1935, pp. 959, 995, 1245; ibid. 1937, pp. 85, 2324.

${ }^{67}$ In the Western Live Stock case, Mr. Justice Stone carefully refrained from interpreting the tax as one imposed on the privilege of publishing. As interpreted, the tax was on the privilege of "providing and selling advertising space in a published journal," measured by gross receipts from the sale of advertising space. Supre note 33, at 257. The tax, therefore, was not measured by receipts from interstate sales. Even so, Mr. Justice Stone thought it important to point out that while there was some interstate value in the receipts from advertising, it was only indirectly derived from interstate commerce, and could not be reached by other states into which the magazine was sent. If the tax had been measured by gross receipts from the sale of the inagazines (including interstate sales), it could not be said that other states into which the magazine was 
the interpretation given the American Manufacturing Co. case in the Storen case. ${ }^{\text {s8 }}$

2. The state of origin may not impose a tax on the privilege of performing activities in the state that are an integral part of interstate sales and measure the tax by unapportioned gross receipts from interstate sales. There are implications that the state may tax directly that portion of gross receipts fairly allocable to the interstate activities performed within the boundaries of the state. There is language from which the inference may be drawn that the state may lay a tax directly on the privilege of making interstate sales. ${ }^{69}$

3. The state of destination may impose a tax confined to a local activity related to interstate sales, if it imposes a tax equal in amount upon some activity related to intrastate sales so that the tax burden imposed by the state involved is the same on the activities related to interstate and intrastate sales; at least in the absence of a showing that a tax has been paid to some other state on activities related to the same interstate sales.

4. The state of destination may impose a tax on the portion of gross receipts from imterstate sales fairly allocable to the activities performed within the state that are an integral part of interstate sales. ${ }^{70}$

sent had no control over them. A possible explanation is that at this point in the opinion Mr. Justice Stone is demonstrating that even if the privilege taxed is not a local activity similar to the manufacturing in the Anierican Mfg. Co. case, still the tax was valid for the reason that all the interstate value tax was allocable to activities performed in New Mexico. Certainly the opinion is not to be read as overruling the American Mfg. Co. case.

6s Mr. Justice Roberts points out that the tax in the American Mfg. Co. case "was upon the privilege of manufacturing within the State and it was permissible to measure the tax by the sales price of the goods produced rather than by their value at the date of manufacture. If the tax there under consideration bad been a sales tax the city could not have measured it by sales consuminated in another State." Supra note 44, at 312-313. The logical inference is that if the tax in the Storen case had been imposed on the privilege of manufacturing it would not have been subject to the cumulative burdens doctrine.

69 Supra note 53.

70 Neither the Storen case nor the Gwin case involved taxes imposed by the state of destination, but the discussion about allocation assunes tbat any state wherein are performed some of the activities that are an integral part of interstate sales, and from which the gross receipts are in part derived, may tax that portion of the receipts fairly allocable to these activities. Moreover the Ficklen case, approvingly cited in the Storen case, involved a tax imposed by the state of destination upon the activities of persons in the district negotiating sales for delivery into the district. The gross receipts by which the tax was measured were commissions and as such were allocable in their entirety to the district for the reason that the interstate activities performed therein gave rise to all the commissions. The case was actually decided on the ground that the activities of the taxpayers were local in character, distinct from interstate commerce, as re-interpreted in the Storen case, and the tax was valid whether or not the activities were an integral part of interstate commerce. 
As has been previously stated, only the future can tell whether the major implications in the newly evolved cumulative burdens doctrine will be followed. This much is certain. A taxpayer seeking to establish immumity from a particular state tax on the ground that its imposition contravenes the commerce clause will do well to ignore the oft-repeated dictum that "no State has the right to lay a tax on interstate commerce in any form." ${ }^{\text {71 }}$ On the contrary he should consider the advice recently given by Circuit Judge Sibley. Commenting on the effect of the recent decisions concerning immunity from taxation he remarked:

"The principle of stare decisis in constitutional interpretations has recently received shattering blows in the Supreme Court, and especially in the field of immunities from general taxation. The increasing social burdens assumed by our governments, both State and national, will require increasing and more searching taxation for their support. Any immunity from equal general taxation appears more and more inconvement and unjust. The recent reexamination of the basis for such immunities has resulted in an upheaval. The current of authority has been turned. For the judicial navigator the cases are no longer the beacons marking out a fixed if tortuous channel. He inust for awhile fix his eyes anew upon the Constitution as the pole star of his firmament and steer his course rather by principle than by precedent." 72

Berketey, Catifornia.

George M. Johnson. 